J. Perinat. Med. 3 (1975) 248

\section{An endocrine model for the diagnosis of intrauterine growth retardation as demonstrated by the determination of total estrogen and pregnandiol 24-hour urinary excretion in 222 at risk pregnancies}

\author{
R. Wolfrum, Ch. Bordasch, J. Holweg \\ Departments of Chemistry (Director: Dr. J. FüHR) and Obstetrics \\ and Gynecology (Director: Dr. J. KöRNER) \\ Allgemeines Krankenhaus Heidberg, Hamburg.
}

Received April 30, 1975. Accepted July 10, 1975.
Today urinary excretion of estrogen as an indicator of possible pregnancies at risk is an accepted parameter. For a long time excretion of estrogen was considered as a so-called fetoplacental indicator; since both fetus and placenta participate in estriol synthesis. However, recent findings indicate $[7,22,23]$ that the fetus is, to some extent, independent of the placenta as far as the synthesis of estriol precursors is concerned. It has also been demonstrated that the capacity of the placenta to form aromatic compounds is not decreased but rather elevated in severely impaired nutrition [21]. Hence decreased estrogen excretion is more probably due to limited synthesis in the fetus than in the placenta. The lack of placental sulfatase is an exception that is hardly of quantitative importance $[6,8]$. Hence the rate of estrogen excretion may be considered a fetal rather than a fetoplacental parameter.

Usually an impairment of the nutritive function of the placenta that is chronic in nature is the basis of the endocrinologically assayable danger to the fetus. If urinary estrogen excretion is decreased it must be assumed that the fetus has already been damaged. Hence for perinatal diagnostic purposes it is desirable to use a purely placental indicator that might indicate danger earlier than estrogen excretion

\section{Curriculum vitae}

Dr. rer. nat. REINHOLD WolfRUM, born 1938, study of chemistry from 1958 to 1964 at the Universities of Freiburg and Munich.

Diploma 1965, Munich, concerned with the total synthesis of glucagon. Doctorate 1969, Hamburg, in the field of organometallic compounds and their cry'stal structure analysis by $X$-rays.

Since 1969 in the Department of Clinical Chemistry at the Heidberg-Hospital, Hamburg.

Current studies deal with the therapy of chronic failure of nutritive placental function.

and that permits us to distinguish between fetal and placental malfunction. Three hormone tests are usually applied: HPL (human placental lactogen) in serum; pregnandiol in urine as an indicator of progesteron metabolism and plasma progesteron.

HPL indicates the rate of proteinsynthesis in the placenta and pregnandiol its steroid biosynthesis. The introduction of radioimmunological tests for HPL has reduced pregnandiol determinations with their well known drawbacks related to urinary analyses. Pregnandiol determinations very often gave false normal 
results [11]. The value of HPL determinations has invited contradictory opinions $[3,4,12,16$, $18,19,20]$. Our own data also indicate that HPL in addition to estrogen determinations does give information on placental function but that this represents no gain in time (unpublished data). Time, however, is of utmost importance. We have retained the use of urinary analysis. Our results with pregnandiol using a previously reported method [24] do not agree with those of Keller [11]. We asked whether estriol excretion was really a fetal parameter. Hence both estrogen and pregnandiol were determined in 24-hour urine samples. A total of 2500 combined hormone analyses were performed in 500 cases from which the 222 reported pregnancies at risk were chosen.

\section{Material and Method}

Estrogen and pregnandiol were determined as described previously $[24,25]$ using internal standards. The method is reliable. Normal values were obtained from a large number of normal women between the 20th and 40th weeks of pregnancy $[24,25]$. 24-hour urines were examined for creatinine (picric acid method, TECHNICON autoanalyser) to test for correct urine collections. Not only "normal" creatinine excretion but also the constant rate of intraindividual excretion served as criteria. Only 24-hour urines were tested. Only the following pregnant women were included:

\section{At least 3 hormone tests ${ }^{1}$ ).}

2. Last hormone analysis at the earliest one week before the end of pregnancy.

3. Pregnancy at risk according to case history or finding; with suspicion of chronic impairment of the feto-placental unit.

4. No acute renal disease and no penicillin treatment [26].

Hormone excretion was considered to be pathological if

\footnotetext{
1) Only a few exceptions were made; e. g. in severe cases, when pregnancy was terminated for clinical reasons and the very low hormone values, or if suspicion of fetal death was confirmed endocrinologically.
}

1. there was no normal rise in hormone excretion; but a stagnant level, particularly for estrogen - for a period of at least 4 weeks, even if this was within the normal range

2. there was a fall in hormone excretion within a few days, even within the normal range, to less than $50 \%$ of the initial value,

3. there was a prolonged slow decline in hormone excretion - even within the normal range

4. many of the values were within a doubtful pathological range $[8,9]$ or below that range

5. particularly estrogen excretion showed ,heterogeneous oscillations", this being a pattern of exretion that occurs frequently in less severe cases of intrauterine growth retardation, that can only be identified at high frequencies of analysis and that is discussed below.

The requirement for "correct information" was met if

1. pathological hormone values were obtained in clinically ascertained risk cases,

2. if an injured child was born after an uneventful pregnancy and if pathological hormone values led us to except impairment,

3. the case history led us to expect a pregnancy at risk with the present pregnancy being normal with a normal child as expected from normal hormone values,

4. a normal child was delivered to an EPH gestosis with a possibly impaired placental function as indicated by pathological pregnandiol excretion, where normal estrogen values led us to expect a normal child,

5. a normal child at term was delivered to a woman with slight EPH gestosis with normal estrogen and pregnandiol values,

6. after the expected term had been exceeded, a healthy full term baby, not postmature, was delivered as was expected from normal pregnandiol values indicating normal placental function and from rising estrogen values, indicating that term had not been exceeded,

7. a postmature baby was delivered after normal term had been exceeded with pathological pregnandiol values indicating decreasing placental function and with decreasing estrogen values indicating postmaturity.

The following risks were included: EPH gestosis $(38.7 \%)$, suspicion of impairment of nutritive placental function without $\mathrm{EPH}$ gestosis $(16.2 \%)$, imminent premature delivery $(13.9 \%)$, postmaturity or uncertain term $(13.5 \%)$, suspicion of impairment of placental function as judged from the case history (9.9\%), hemorrhage $(6.7 \%)$, diabetes $(0.9 \%)$.

First all data were computed. The results of hormone analyses without further differentiation were expected to indicate whether risk to the fetus had been assessed. Thereafter a detailed etiological analysis was performed. 
Tab. I. Reliability of estrogen and pregnandiol urinary excretion if assessed individually or together ( $\mathrm{n}=$ normal, $\mathrm{p}=$ pathological).

\begin{tabular}{|c|c|c|c|c|c|c|c|c|c|c|c|c|c|}
\hline & \multirow[t]{3}{*}{ total } & \multicolumn{4}{|c|}{ estrogen } & \multicolumn{4}{|c|}{ pregnandiol } & \multicolumn{4}{|c|}{ estrogen/pregnandiol } \\
\hline & & \multicolumn{2}{|c|}{ correct } & \multirow{2}{*}{$\begin{array}{c}\text { false } \\
\mathrm{p}\end{array}$} & \multirow{2}{*}{$\begin{array}{c}\text { false } \\
\mathrm{n}\end{array}$} & \multicolumn{2}{|c|}{ correct } & \multirow{2}{*}{$\begin{array}{c}\text { false } \\
\mathrm{p}\end{array}$} & \multirow{2}{*}{$\begin{array}{c}\text { false } \\
\mathrm{n}\end{array}$} & \multicolumn{2}{|c|}{ correct } & \multirow{2}{*}{$\begin{array}{c}\text { false } \\
\mathrm{p} \\
\end{array}$} & \multirow{2}{*}{$\begin{array}{c}\text { false } \\
\mathbf{n}\end{array}$} \\
\hline & & $\mathrm{n}$ & $\mathrm{p}$ & & & $\mathrm{n}$ & $\mathrm{p}$ & & & $\mathrm{n}$ & $\mathrm{p}$ & & \\
\hline & 222 & 89 & 111 & 4 & 18 & 53 & 129 & 15 & 25 & 49 & 149 & 18 & 6 \\
\hline$\%$ & 100 & 40.1 & 50.0 & 1.8 & 8.1 & 23.8 & 58.1 & 6.7 & 11.2 & 22.1 & 67.1 & 8.1 & 2.7 \\
\hline
\end{tabular}

Tab. II. Separation of pregnancies into risk groups depending on the combined excretion of estrogen and pregnandiol. Types of risk in the groups. Frequency of SGA infants in the groups. $\mathrm{E}=$ estrogen, $\mathrm{P}=$ pregnandiol, $\mathrm{SIP}=$ suspected insufficiency of nutritive placental function

\begin{tabular}{|c|c|c|c|c|c|c|c|c|c|c|}
\hline $\begin{array}{l}\text { hormone } \\
\text { excretion }\end{array}$ & $\begin{array}{l}\text { risk } \\
\text { group }\end{array}$ & $\mathbf{n}$ & & risk types & $\begin{array}{c}\text { number of } \\
\text { cases } \\
\text { (percent) }\end{array}$ & - & .. & & $\begin{array}{l}\text { num- } \\
\text { ber } \\
\text { of } \\
\text { dys- } \\
\text { mature } \\
\text { new- } \\
\text { borns }\end{array}$ & $\begin{array}{c}\text { fre- } \\
\text { quency } \\
\text { of } \\
\text { SGA } \\
\text { in } \\
\%\end{array}$ \\
\hline E.normal & & & $\begin{array}{l}\text { term } \\
\text { history }\end{array}$ & $\begin{array}{l}\text { EPH- } \\
\text { gestosis }\end{array}$ & $\begin{array}{l}\text { imminent } \\
\text { premature } \\
\text { labor }\end{array}$ & & & & 0 & 0 \\
\hline P normal & I & 55 & $\begin{array}{c}35 \\
(63.9) \\
\end{array}$ & $\begin{array}{c}15 \\
(27.2)\end{array}$ & $\begin{array}{c}5 \\
(9.0) \\
\end{array}$ & & & & & \\
\hline E normal & & & $\begin{array}{l}\text { EPH- } \\
\text { gestosis }\end{array}$ & $\begin{array}{l}\text { term } \\
\text { history }\end{array}$ & bleeding & $\begin{array}{c}\text { SIP } \\
\text { without } \\
\text { EPH- } \\
\text { gestosis }\end{array}$ & $\begin{array}{l}\text { imminent } \\
\text { premature } \\
\text { labor }\end{array}$ & & 6 & 11.5 \\
\hline P pathol. & II & 52 & $\begin{array}{c}28 \\
(53.8) \\
\end{array}$ & $\begin{array}{c}10 \\
(19.2)\end{array}$ & $\begin{array}{c}7 \\
(13.4) \\
\end{array}$ & $\begin{array}{c}5 \\
(9.6) \\
\end{array}$ & $\begin{array}{c}2 \\
(3.8)\end{array}$ & & & \\
\hline \multirow[t]{2}{*}{$\begin{array}{l}\text { E pathol. } \\
\text { P normal }\end{array}$} & III & 23 & $\begin{array}{c}\text { imminent } \\
\text { premature } \\
\text { labor }\end{array}$ & $\begin{array}{c}\text { SIP } \\
\text { without } \\
\text { EPH- } \\
\text { gestosis }\end{array}$ & $\begin{array}{l}\text { EPH- } \\
\text { gestosis }\end{array}$ & $\begin{array}{l}\text { term } \\
\text { history }\end{array}$ & & & 6 & 26.0 \\
\hline & & & $\begin{array}{c}8 \\
(34.7) \\
\end{array}$ & $\begin{array}{c}7 \\
(30.4) \\
\end{array}$ & $\begin{array}{c}5 \\
(21.7) \\
\end{array}$ & $\begin{array}{c}3 \\
(13.0) \\
\end{array}$ & & . & & \\
\hline E pathol. & & & $\begin{array}{l}\text { EPH- } \\
\text { gestosis }\end{array}$ & $\begin{array}{l}\text { SIP } \\
\text { without } \\
\text { EPH- } \\
\text { gestosis }\end{array}$ & $\begin{array}{l}\text { imminent } \\
\text { premature } \\
\text { labor }\end{array}$ & bleeding & $\begin{array}{c}\text { term } \\
\text { history }\end{array}$ & $\begin{array}{l}\text { dia- } \\
\text { betes }\end{array}$ & 51 & 55.4 \\
\hline P pathol. & IV & 92 & $\begin{array}{c}38 \\
(41.3)\end{array}$ & $\begin{array}{c}24 \\
(26.0)\end{array}$ & $\begin{array}{c}16 \\
(17.3)\end{array}$ & $\begin{array}{c}8 \\
(8.6)\end{array}$ & $\begin{array}{c}4 \\
(4.3)\end{array}$ & $\begin{array}{c}2 \\
(2.1)\end{array}$ & & \\
\hline
\end{tabular}

\section{Results}

\subsection{All data}

A total of 2211 estrogen and pregnandiol determinations were performed in 222 pregnancies; an average of 9 daily urines being analysed per patient. Reliability was separately determined for each hormone and determined as a diagnostic unit. The risk is considered to be determined when both hormones are assayed, if the ex- cretion of either hormone is pathological; results are shown in Tab. I.

The lowest rate of false normal findings is observed if both hormones are evaluated. These are five cases with premature labor, of whom three resulted in premature births and two in the delivery of full term babies after successful tocolysis. The 6 th case is genuinely postmature with the delivery of an otherwise healthy child. 
In none of these cases with normal hormone values was a small for date infant delivered.

\subsection{Risk groups and types of risk}

We shall deal with the four possible hormone combinations separately. Risk groups will be delineated at the same time. The four groups at risk are devided according to the type of risk. The largest number of SGA infants is found in risk group IV (pathological excretion of both hormones). Results are summarized in Tab. II.

\subsubsection{Risk group I}

As expected this includes mainly pregnancies that were at greater risk because of case history or postmaturity but resulted after normal clinical courses in a healthy full term baby. The 15 cases of light, mostly monosymptomatic (slight hypertension) EPH gestosis belong here. As already mentioned the risks "imminent premature delivery" and "postmaturity" may belong to group I and cannot be securely distinguished by combined hormone determinations.

When deciding whether estrogen excretion is rising (term has not yet occurred) or falling (postmature) it must be remembered that daily variations in estrogen excretion are about $20 \%$ (see below). As expected there is no intrauterine growth retardation in group $I$.

\subsubsection{Risk group II}

The hormonal picture is typical for EHP gestosis and is most frequently found if examination is begun early as soon as signs of hypertonia are observed. In light or well treated cases there is no change in the excretion of hormones up to the end of gestation. Predominantly a normal child is delivered. Only 6 out of 66 maldeveloped children showed the hormone picture of group II. In three of these an $\mathrm{EPH}$ gestosis was also present, in two bleeding occurred and in one premature labour set in. Untreated EPH gestosis terminates within weeks or months mostly in group IV indicating fetal injury as judged from altered estrogen excretion. There is a very small number of cases with premature labor which corresponds with a small correlation between imminent premature labor and impairment of placental function. Intrauterine growth retardation was found in $11.5 \%$. This frequency indicated that this type of risk is not always discovered by estrogen determinations alone.

\subsubsection{Risk group III}

Injury of the fetus without demonstrable endocrine impairment of placental function (pathological placental parameter) should be the exception, rather than the rule. The small number of cases thus agrees with our expectation. Yet this hormone pattern, in comparison to that of group II, indicates a greater degree of risk, as shown by the greater frequency of SGA infants in group III. The hormone excretion in anencephaly is typical for group III (one case). Hence pathological estrogen excretion with normal excretion of pregnandiol should raise suspicion of this anomaly. The six pregnancies with intrauterine SGA infants in group III consisted of $2 \mathrm{EPH}$ gestoses, three premature labors and one functional disturbance of the placenta without other symptoms.

\subsubsection{Risk group IV}

As expected this contains the largest number of cases, severe gestoses, most infants small for date and the smallest number of false pathological results (one case). The risk type "EPH gestosis" and "suspected impairment of nutritive placental function" form $67.3 \%$ of all cases of this group. A total of 63 SGA infants was born. The mothers of 51 of these had the hormone excretion of risk group IV (frequency $55.4 \%$ ). In 24 of these 51 mothers a usually severe EPH gestosis was present; in 18 the case history or the present state indicated impairment of the nutritive function of the placenta; in the remaining 9 premature labor or hemorrhage were found. The relatively large percentage of SGA infants whose mothers, except for a history of placental insufficiency or low fundus, showed no clinical signs of chronic placental impairment, was surprising. A total of 19 SGA newborns (one from group III), i. e. $30.1 \%$ of the total number, was found. Such a high incidence of SGA infants in clinically apparently normal 
pregnancies underlines the need for general endocrine surveillance during gestation.

The above statistics confirm the expectation that chronic placental insufficiency with or without EPH gestosis is one of the main indications for endocrine diagnosis. Figs. 1 and 2 give examples.

Fig. 1 shows the typical estrogen and pregnandiol excretion pattern in a 32-year-old woman (primipara) with suspected intrauterine growth retardation without EPH gestosis. At first a normal rise in estrogen excretion was observed. The
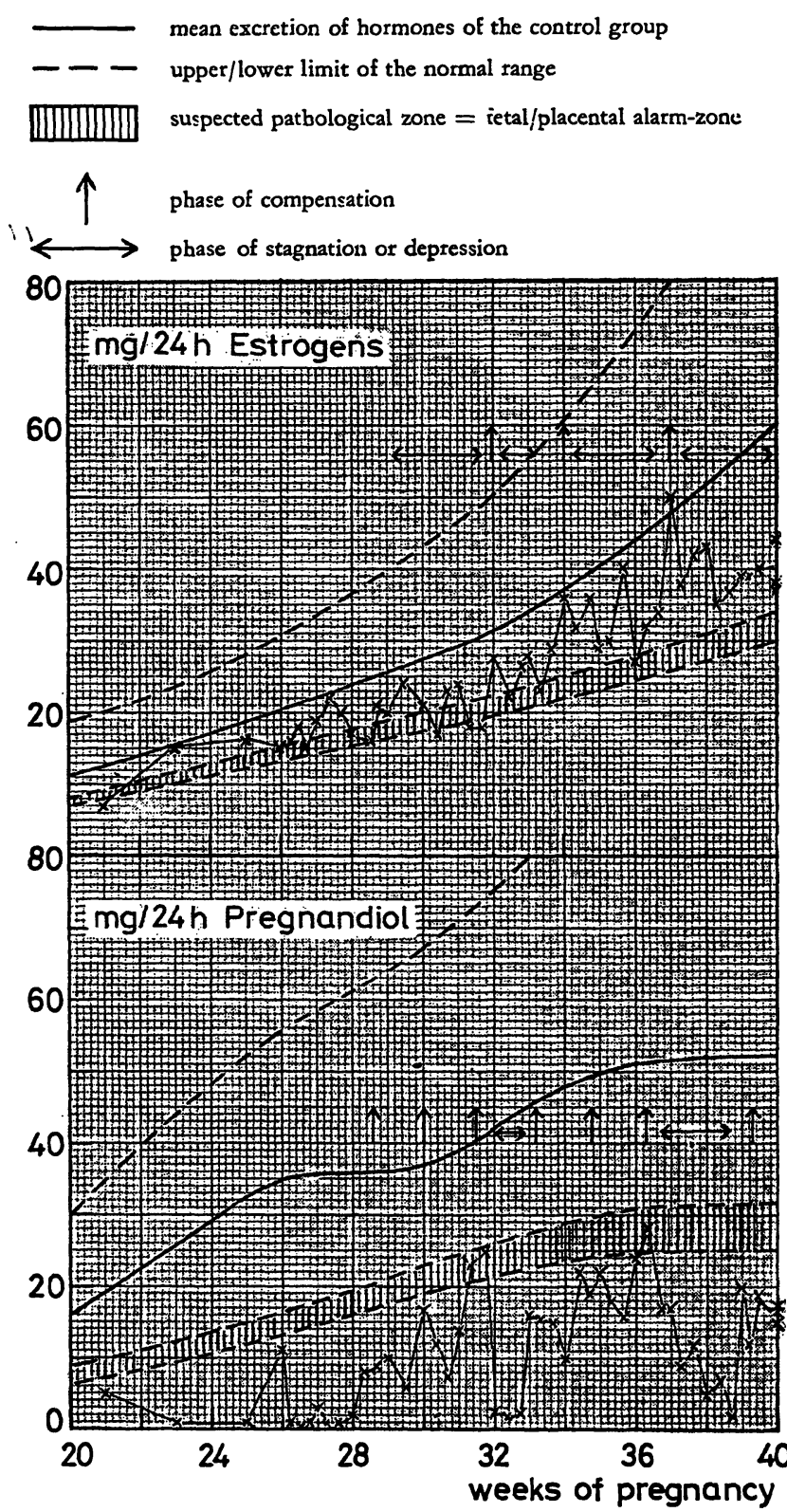

Fig. 1. Example of pregnancy of risk-group IV. 32 year old primipara, no EPH-gestosis. Newborn: $2700 \mathrm{~g} / 50 \mathrm{~cm}$, APGAR 10/10. first pathological result would have raised no suspicion if it had been obtained alone. The pregnandiol excretion curve, however, indicated right from the start the presence of considerably impaired placental function. The further course shows alternating phases of placental compensation (rising pregnandiol excretion) and depression (falling excretion). Twice (31st/32nd and $36 \mathrm{th} / 37$ th week) the maximum of pregnandiol excretion shows a clear compensation by the fetus (a rise of the previously unaltered estrogen excretion). This can be interpreted to indicate a reaction to the transient improvement of placental function. The general endocrine finding clearly indicates a growth retarded fetus, which, however, need not be severely damaged. A newborn weighing $2700 \mathrm{~g} / 50 \mathrm{~cm}$ with an APGAR-score of $10 / 10$ corresponds to that conclusion.

Fig. 2 shows two cases with severe gestosis. Both curves are examples for successfully and early treated cases. The two single values in the 33rd week show the end of a risk pregnancy that was not controlled and that was treated too late. The fetus died in utero.

\section{Case 1}

A 26-year-old secondipara, EPH gestosis in the 2nd half of the 1st pregnancy (weight $107 \mathrm{~kg}$ ), child $4200 \mathrm{~g} / 55 \mathrm{~cm}$. This pregnancy: hypertension from 12th week, endocrine control started from 20th week. Alternate continuous outpatient and hospital treatment (Lasix ${ }^{\circledR}$, Catapresan ${ }^{\circledR}$, Hygroton $($ ). Weight gain from 90 to $109 \mathrm{~kg}$ before delivery ending in uncomplicated birth of healthy mature girl. $3000 \mathrm{~g} / 50 \mathrm{~cm}$; Apgar 10/10. Strongly infarcted placenta. The start of a critical change can be observed in the excretion of both hormones.

This case is proof that good treatment of EPH gestosis can prevent severe chronic disturbance in the feto-placental unit and hence the delivery of an SGA infant. The case also shows what we consider to be "heterogeneous variations" in hormone excretion. A quick glance at estrogen excretion does not seem to indicate fetal risk. Most values appear normal. However, it can be seen that for both hormones periods of compensation and depression traverse the whole range of normal values and that they vary by more than $\mathbf{5 0} \%$ within a few days. This does not occur normally. Thus in one pregnant woman in the 23/24th week the standard deviation of 


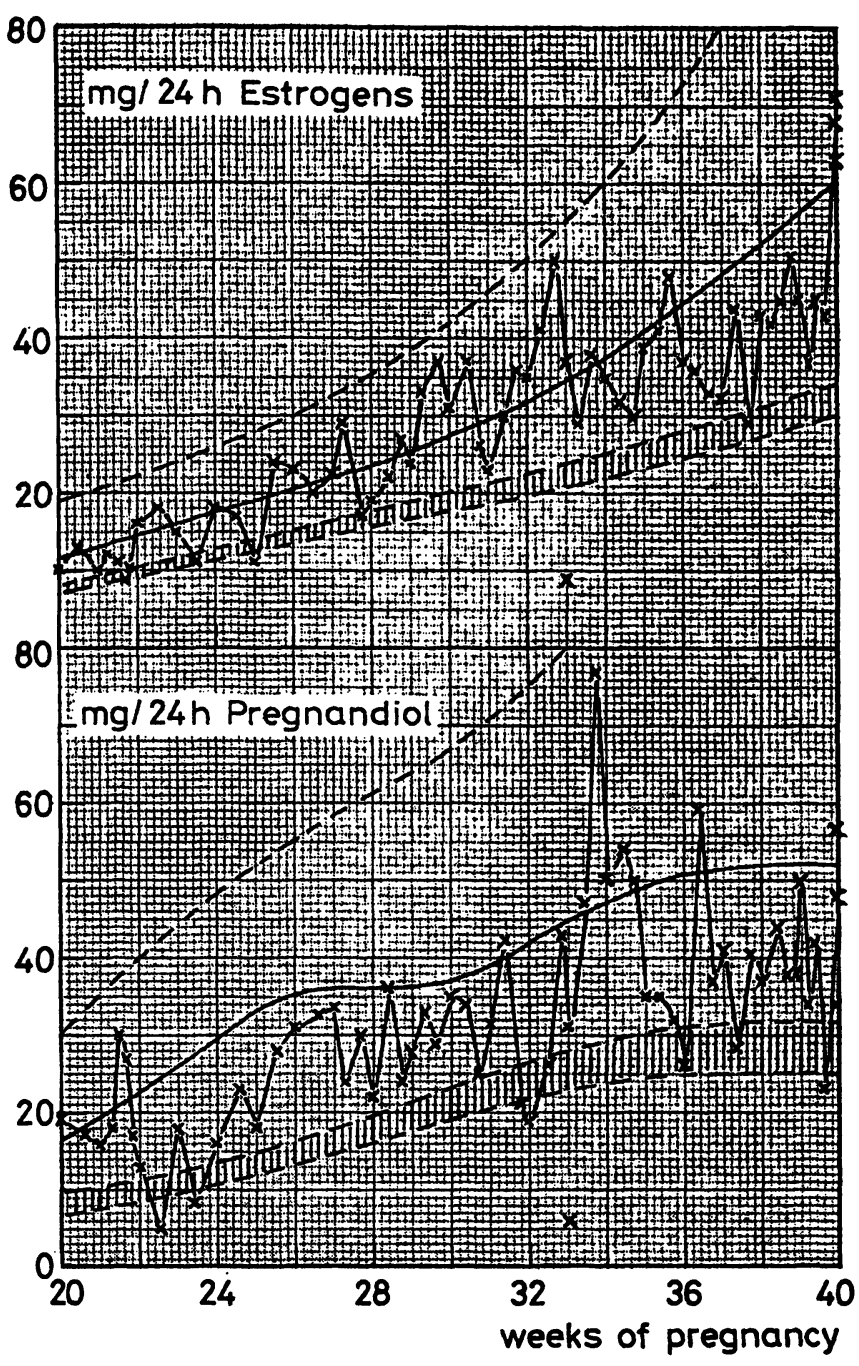

Fig. 2. Example of two pregnancies with severe EPHgestosis.

Case 1: Supervision since the twentieth week. Newborn: $3000 \mathrm{~g} / 50 \mathrm{~cm}$, Apgar 10/10.

Case 2: Single determination during the 33rd week, no supervision. Fetal death during the 33rd week.

estrogen excretion for 10 successive daily periods was $\mathrm{s}=3.5 \mathrm{mg} / 24 \mathrm{hrs}$ with $\overline{\mathrm{x}}=18.1 \mathrm{mg} / 24 \mathrm{hrs}$ and $\mathrm{V}=19.1 \%$ and $\mathrm{s}=4,4 \mathrm{mg} / 24 \mathrm{hrs}, \overline{\mathrm{x}}=18,9$ $\mathrm{mg} / 24 \mathrm{hrs}, \mathrm{V}=23,2 \%$ for pregnandiol excretion. The coefficient of variation for creatinin excretion was $\mathrm{V}=5.3 \%$. In another ten 24-hour urine samples obtained in the 38/39th week in another woman we found $\mathrm{s}=8.4$ and $\overline{\mathrm{x}}=51.8$ $\mathrm{mg} / 24$ hours and $\mathrm{V}=16.2 \%$ for estrogen and $\mathrm{s}=5.2, \overline{\mathrm{x}}=58.6 \mathrm{mg} / 24 \mathrm{hrs}$ and $\mathrm{V}=8.8 \%$ for pregnandiol. The coefficient of variation for intraindividual creatinine excretion was $9.0 \%$. These values may be considered to be representative. Variations that exceed these values, even though they lie within the norm, must be viewed as pathological. We suggest that this be called "heterogeneous variations".

Case 2 also was a severe EPH gestosis with no hormonal control or treatment. The dead infant $(1650 \mathrm{~g}, 44 \mathrm{~cm})$ requires no comment.

\subsection{Other problems}

\section{a) Critical limit of hormone excretion}

Some workers [17] consider an endocrine parameter to be not only normal or pathological but assign it a certain weight for estimating the risk, by evaluating its transverse position according to a point system. (e. g. estrogen excretion $=$ low normal $=1$ point, in dubious pathological range 2 points etc.).

This leads to the following question: Is there a critical lower limit for estrogen excretion below which it is better to terminate pregnancy, i. e. for which chances for survival are better outside the uterus than within.

Our data contain 10 perinatal deaths, of which one was an anencephalus. Another two can be eliminated since they died before the 30th week of gestation. Of the remaining 7 , in four the fetus died in utero, in 3 cases within 12 days after birth. Hence there are very few cases. Fig. 3 shows the lowest estrogen value found in 8 pregnancies between the 30th and 40th week. Evidently there is a crossing over of values, the

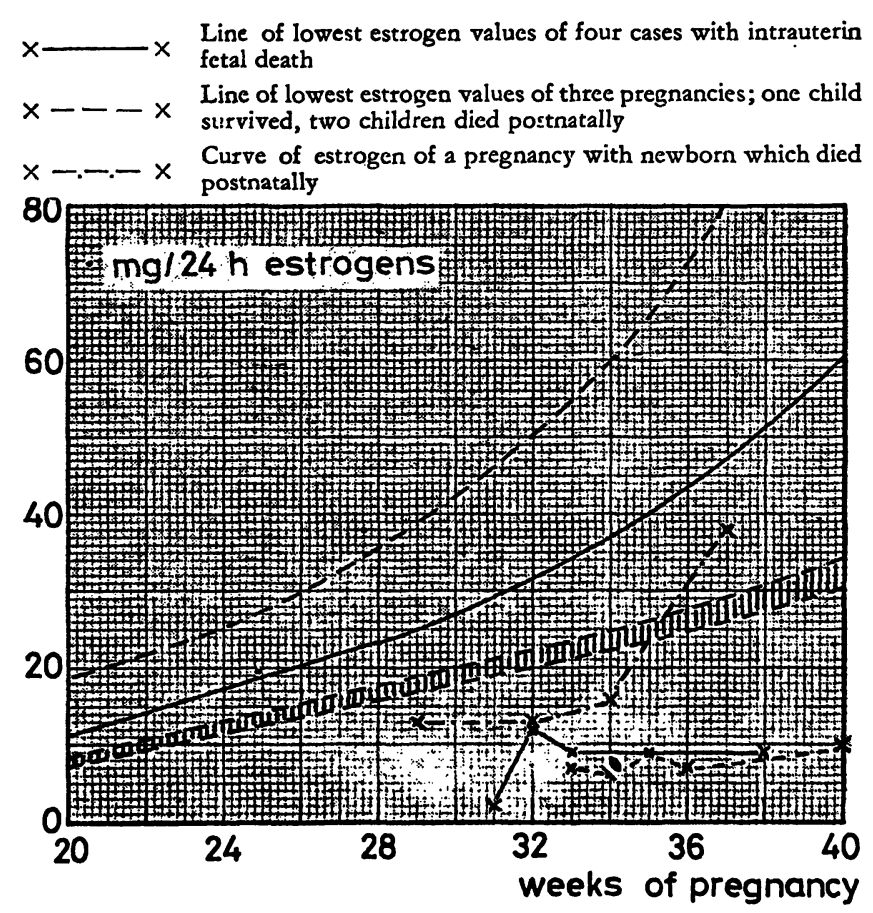

Fig. 3. Critical limit of estrogen excretion. 
lowest value being for a surviving child $(6 \mathrm{mg} /$ $24 \mathrm{hrs}$ in the 34th week). The dot dash line shows estrogen excretion for a severe EPH gestosis. The child died 3 days after delivery. Hence, with great reservations it may be concluded that:

1. There is no lower limit of estrogen excretion.

2. Estrogen values between 6 and $10 \mathrm{mg} / 24 \mathrm{hrs}$ are compatible with intrauterine life in the last 6 weeks of gestation. Postnatal survival, however, is rare.

3. If estrogen values fall, then at the latest for a value of $10 \mathrm{mg} / 24 \mathrm{hrs}$ pregnancy should be terminated.

4. If estrogen values show a tendency to rise from low initial values there is less risk of intrauterine death. However, the postnatal risk remains.

5. Estrogen excretion of less than $6 \mathrm{mg} / 24 \mathrm{hrs}$ in the last 10 weeks of pregnancy is incompatible with intrauterine life (rare exceptions: sulfatase deficiency, 16-hydroxylase deficiency, adrenal hypoplasia, anencephaly). Intrauterine death may, however, also occur at higher values.

6. There seems no value in devising a point system ascribing different weight factors to individual estrogen values. Only normal or abnormal states can be determined, with the whole curve being considered.

\section{b) Fall in estrogen, time factor, diabetes}

If we define a fall in estrogen as a sudden precipitous decrease from one day to the next without return to normal values, then this was never observed in living fetuses. If it does occur the fetus is most probably dead or dying. It follows that the often discussed time factor in the delay with which laboratory results are obtained is unimportant in terms of hours or even days. From that point of view plasma against 24-hour urine analyses are equally valuable. It is much more important to have precise data determined repeatedly so that the time course of excretion can be assessed. The only exception in our opinion are diabetic mothers in the last weeks of pregnancy where daily estrogen determinations and less so pregnandiol determinations, are of certain value.

\section{Discussion}

The most important result of this work is the frequently observed temporal shift between decreased estrogen excretion and pregnandiol excretion in chronic impairment of the nutritive function of the placenta. This can only be understood if we assume that estrogen excretion is limited not by the placental but by the fetal compartment and that the fetus is capable of synthetizing normal amounts of estrogen precursors from $C 2$ groups even in chronic placental insufficiency. A number of partly new results $[5,7,14,15,21,22,23]$ that cannot be dealt with in detail here support this conclusion. It may be assumed, at least as a working hypothesis, that decreased estrogen excretion during pregnancy is probably due to a disturbance in the fetal adrenal or liver and is thus secondary to primary placental insufficiency. Placental sulfatase lack, fetal adrenal hypoplasia and anencephalus are exceptions, as mentioned previously.

In a similar fashion pregnandiol reflects placental function $[1,2,8,9,10,13]$. Not only the fetus but also the placenta is capable of compensating some defects [21] as witnessed by capillary hyperplasia in hypofunction. This compensation may lead to improved hormone excretion during the further course of pregnancy after a period of low hormone excretion. Such cases are usually called "erroneously pathological" in retrospective.

Our model with 4 factors (estrogen = fetus, placenta = pregnandiol, fetal and placental compensation) explains the results of this work. Particularly it seems proven that pregnandiol reflects the nutritive function of the placenta and not some other function that may be unimportant for fetal well being. This stresses the finding of NAEYE [14] showing that the fetal adrenal cortex and other organs are retarded in weight to a greater extent in intrauterine growth retardation than the birth weights of such newborns. Less severe injury to fetal organs could thus be possible without macroscopically visible dystrophy of the fetus: This would explain why in risk group IV only slightly more than half the infants were SGA. This would also lead to 
the conclusion that cases in risk group II are to be considered as at risk and should be treated prophylactically. If we consider it our aim to diagnose all cases with placental insufficiency, if possible before injury to the fetus is severe, then we must not only have hormonal control but also hormonal preventive control.

We believe that the determination of both estrogen and pregnandiol is a reliable system for this purpose. In our perinatal practice this interpretation of both endocrine parameters has proved of value. A current study indicates that three combined hormone determinations between weeks 20 and 26 are of great value for the prognosis of risk of intrauterine growth retardation. In contrast to many others, e. g. Kuss [12], we believe that in the future placental parameters such as pregnandiol will be of considerable significance for the early recognition of chronic placental insufficiency. Early diagnosis will be particularly decisive if and when a reliable therapy is discovered and thus fetal injury is, perhaps, avoided. This is being studied.

\section{Summary}

A reliable method for surveillance of chronic impairment of nutritive placental function is described. The techniques are simple, tested for their reliability, without nced for isotopes or special apparatus and hence inexpensive.

Using 222 pregnancies at risk it is shown that the simultaneous determination of a fetal (estrogen) and a placental (pregnandiol) parameter makes the early diagnosis of intrautcrine growth retardation possible. Estrogen diagnosis alone has a reliability of $\mathbf{9 0 . 1 \%}$ with $\mathbf{1 . 8} \%$ falsely pathological and $8.1 \%$ falsely normal findings (Tab. I). Simultaneous pregnandiol determinations increase the number of falsely pathological findings to $8.1 \%$ but reduce that of falsely normal ones to $2.7 \%$. No small for date (SGA) infants are found here. It consists of 5 cases of imminent ( 3 times actual) premature delivery and one postmature one. Hence our technique indicates the risk of intrauterine growth retardation in all cases but not the risk of premature or postmature delivery.

Early diagnosis (from week 20) indicates that impairment of placental function as indicated by decreased pregnandiol excretion, occurs weeks or months earlier than decreased estrogen excretion (Fig. 1). This can be explained only by assuming that the rate of estrogen excretion is usually not dependent on the placenta but on the capacity of the fetal adrenals and liver. Thus our results indirectly confirm those of others who claim that the fetus can synthetize estrogen precursors without the need for placental pregnenolon by using acetate. Thus it appears that the synthetic pathway that is independent of the placenta at the beginning plays a quantitative role also. Since the placenta can form aromatic compounds even when its nutritive function is severely impaired, our finding is further proof that estrogen excretion reflects fetal and not fetoplacental well-being. It follows that pathological estrogen excretion indicates, fetal injury that has already occurred. The requirement that a sensitive parameter of placental function be hence determined in time is met by pregnandiol assays. Low pregnandiol excretion often precedes low estrogen excretion which leads to a SGA infant, indicating that pregnandiol excretion is closely correlated to placental nutritive function.

Synthetic reactions in the fetus require energy and hence depend on the placenta. Normal estrogen excretion frequently observed in the presence of prolonged decreased pregnandiol excretion must hence indicate that the fetus can compensate for placental insufficiency. In the placenta this can be demonstrated by hyperplasia of the capillaries. This is reflected in the undulating excretion of pregnandiol (Fig. 1), where compensation (new vessel formation) and depression (lesion of vessels) make these contradictory placental processes "visible". The functional unity of the fetus and the placenta is finally also demonstrated by the fact that each prolonged compensatory phase of the placenta is responded to by the fetus with a clearly compensatory excretion of estrogen (Fig. 1). Decreasing pregnandiol excretion, on the other hand, is accompanied by stagnation in estrogen excretion, indicating delayed fetal growth. This paper is the first to demonstrate a relationship between placental morphology and fetoplacental endocrinology. Four risk groups are proposed (Tab. II). The model is based on 4 assumptions:

1. Estrogen excretion is a fetal and not a fetoplacental parameter;

2. Pregnandiol excretion is a parameter of placental nutritive function;

3. Fetal compensatory capacity;

4. Placental compensatory capacity.

The model permits us to interpret our data. The frequency of SGA infants increases from risk group I (normal excretion of both hormones, no SGA infants), through risk group II (only pregnandiol excretion pathological, $11.5 \%$ SGA newborns) and risk group III (only estrogen excretion pathological, 26\% SGA infants) to risk group IV (both hormone excretions pathological,55.4\% SGA infants). The degree of risk can be estimated with our model. Risk group II indicatcs slight, beginning EPH gestosis. 'Treatment in time maintains normal estrogen excretion with frequently low pregnandiol valucs. If control and treatment are neglected the picture frequently changes to group IV and danger to the fetus is considerably incrensed (Fig. 2). 
It is slowly being realized in perinatal medicine that the therapy of chronic placental insufficiency must be prolonged in order to be successful. Early diagnosis is a prime requirement. Our data show that this is possible in the case of placental insufficiency before fetal damage occurs. This makes early treatment possible. The large number of
SGA newborns in clinically apparently normal pregnancies $(30.1 \%$ of all intrauterine growth retardations) suggests that all pregnancies should be controlled endocrinologically. This can only be realized by cooperation between clinicians and practitioners.

Keywords: Endocrine model, intrauterine growth retardation; nutritive placental function, pregnandiol, total estrogen.

\section{Zusammenfassung}

Ein endokrinologisches Modell zur Diagnose der intrauterinen Wachstumsverzögerung, demonstriert durch Bestimmung der Gesamtöstrogen- und Pregnandiolausscheidung bei 222 Risikoschwangerschaften.

Es wird über ein praktikables, treffsicheres endokrinologisches System zur Überwachung der Schwangerschaft bei chronischer Störung der nutritiven Plazentafunktion berichtet. Die zur Hormonanalyse verwendeten Methoden sind einfach, hinsichtlich ihrer Zuverlässigkeit geprüft, ohne Verwendung radioaktiver Isotope oder spezieller Meßgeräte durchführbar und somit jedem Laboratorium ohne großen Kostenaufwand zugänglich.

An Hand einer Statistik von 222 Risikoschwangerschaften wird nachgewiesen, daß bei gleichzeitiger Bestimmung eines fetalen (Östrogene) und plazentaren (Pregnandiol) Parameters das Risiko der intrauterinen Wachstumsstörung mit großer Sicherheit frühzeitig diagnostiziert werden kann. Die alleinige Östrogenanalyse ergibt eine Treffsicherheit von $90,1 \%$ bei $1,8 \%$ falsch pathologischen und 8,1\% falsch normalen Befunden (Tab. I). Durch die zusätzliche Pregnandiolanalyse erhöht sich bei gemeinsamer Beurteilung zwar die Zahl der falsch pathologischen Hormonbefunde auf 8,1\%, jedoch wird gleichzeitig die wichtigere Zahl der falsch normalen Befunde auf 2,7\% reduziert. Dieses Restkollektiv enthält keine dystrophen Neugeborenen. Es setzt sich zusammen aus 5 Fällen mit drohender (davon dreimal erfolger) Frühgeburt und einer echten Übertragung. Somit wird in unserer Statistik durch die kombinierte Hormonbestimmung das Risiko der intrauterinen Wachstumsverzögerung in allen Fällen angezeigt, nicht jedoch das Risiko der drohenden Frühgeburt und der Übertragung.

Bei frühzeitigem Beginn der endokrinologischen Diagnostik (ab 20. Woche) stellt sich heraus, daß eine Störung der Plazentafunktion durch niedrige Pregnandiolausscheidung Wochen bis Monate früher als durch niedrige Östrogenausscheidung signalisiert wird (Abb. 1). Dieses Ergebnis ist nur dann zu erklären, wenn man annimmt, daß die Höhe der Östrogenausscheidung in der Regel nicht von der Plazenta limitiert wird sondern von der Funktionsfähigkeit der fetalen Leber und Nebennierenrinde. Somit bestätigen unsere Befunde indirekt die Mitteilungen anderer Autoren, wonach der Fet bei der Synthese von Östrogenvorstufen nicht auf das plazentare Pregnenolon angewiesen ist sondern das Steroidgerüst de novo aus Acetat selbst zu bilden vermag. Der in den Anfangsstufen plazentaunabhängige Synthese- weg scheint daher nach unseren Beobachtungen auch quantitativ eine Rolle zu spielen. Unter Einbeziehung der experimentell bewiesenen Tatsache, da $\beta$ die Aromatisierungskapazität der Plazenta selbst bei schwer gestörter nutritiver Funktion anscheinend nicht beeinträchtigt wird, kann unsere Studie als ein weiterer Beweis dafür gelten, $\mathrm{da} ß$ die Östrogenausscheidung weniger einen fetoplazentaren sondern vielmehr einen fetalen Parameter repräsentiert.

Die wichtige klinische Konsequenz hieraus ist, daß bei pathologischer Östriolausscheidung eine bereits eingetreteñe Schädigung des Feten angenommen werden muß. Die weitere Konsequenz ist die Forderung nach einem plazentaren Parameter, der vor allen Dingen empfindlich, d.h. frühzeitig auf Plazentafunktionsstörungen reagieren muß. Die vorliegende Arbeit beweist, daß die Pregnandiolausscheidung nach unserer Methodik, im Gegensatz zu anderen Ergebnissen, einen solchen empfindlichen plazentaren Indikator darstellt. $\mathrm{Da}$ niedriger Pregnandiolausscheidung häufig niedrige Östrogenausscheidung mit einem dystrophen Kind folgen, ist gleichzeitig der Beweis erbracht, da $\beta$ die Pregnandiolausscheidung auch mit der nutritiven Partialfunktion der Plazenta eng korreliert ist.

Energieverbrauchende Synthesereaktionen können im Feten naturgemäß nicht völlig plazentaunabhängig stattfinden. Zur Erklärung der von uns häufig beobachteten normalen Östrogenausscheidung selbst bei langfristig pathologischer Pregnandiolausscheidung muß daher zusätzlich eine gewisse Kompensationsfähigkeit des Feten im endokrinologischen Sinne angenommen werden, wie sie vom respiratorischen Bereich her bekannt ist. Eine solche Kompensationsfähigkeit läßt sich für die Plazenta morphologisch in Form von Kapillarhyperplasie nachweisen. Sie findet ihren endokrinologischen Niederschlag in wellenförmigen Pregnandiolausscheidungskurven (Abb. 1), bei denen Phasen der Kompénsation (Gefäßneubildung) und Depression (Gefäßschädigung usw.) die beiden konkurrierenden Vorgänge in der Plazenta ,sichtbar" machen. Die fetoplazentare Funktionseinheit wird schließlich endokrinologisch dadurch demonstriert, daß eine jeweils längere plazentare Kompensationsphase vom Feten durch einen deutlichen kompensatorischen Östrogenanstieg beantwortet wiṛ (Abb. 1), während abfallende Pregnandiolausscheidung vorwiegend von Stagnationsphasen in der Óstriolausscheidung, gleichbedeutend mit verzögertem fetalen Wachstum, begleitet ist. Mit der vor- 
liegenden Arbeit wird somit erstmals der Zusammenhang zwischen Plazentamorphologie und fetoplazentarer Endokrinologie dargelegt.

Unter Zusammenfassung der soeben diskutierten Faktoren wird, ausgehend von den vier möglichen Kombinationen der Ostrogen- und Pregnandiolausscheidung, ein System von vier Risikogruppen vorgeschlagen (Tab. II). Das Modell stützt sich auf vier Thesen:

1. Östrogenausscheidung $=$ fetaler (nicht fetoplazentarer) Parameter.

2. Pregnandiolausscheidung $=$ Parameter der nutritiven Plazentafunktion.

3. Endokrinologische Kompensationsfähigkeit des Feten.

4. Endokrinologische Kompensationsfähigkeit der Plazenta.

Das Modell gestattet eine zwanglose Erklärung der Ergebnisse unserer Statistik. Die Häufigkeit dystropher Neugeborener nimmt zu von Risikogruppe I (Ostrogen- und Pregnandiolausscheidung normal, keine dystrophen Kinder) über Risikogruppe II (nur Pregnandiolausscheidung pathologisch, 11,5\% dystrophe Kinder) und Risikogruppe III (nur Östrogenausscheidung pathologisch, 26\% dystrophe Kinder) zu Risikogruppe IV (beide Hormonparameter pathologisch, 55,4\% dystrophe Kinder). Durch unser Modell wird es daher möglich, die Höhe des Risikos der intrauterinen Wachstumsretardierung abzuschätzen. So ist eine Hormonausscheidung der Risikogruppe II typisch für die leichte bzw. beginnende EPH-Gestose. Bei rechtzeitiger, guter Behandlung bleibt es bei normalem Ostrogenanstieg mit oft weiterhin niedrigen Pregnandiolwerten. Wird jedoch eine Überwachung und Therapie unterlassen, dann mündet die Hormonausscheidung der Gruppe II häufig in das Bild der Risikogruppe IV und die Gefährdung für den Feten wächst erheblich (Fig. 2).

Es setzt sich in der Perinatalmedizin langsam die Erkenntnis durch, daß eine Therapic der chronisch gestörten nutritiven Plazentafunktion nur durch langfristige Anwendung Erfolg verspricht. Die Frühdiagnose ist Bedingung für ein solches Vorgehen. Unsere Untersuchungen zeigen, daß mit der kombinierten Östrogen- und Pregnandiolbestimmung die verminderte nutritive Plazentafunktion schon vor Eintritt einer Schädigung des Feten erkannt werden kann. Dadurch sind langfristige vorbeugende therapeutische Maßnahmen möglich, die nach unserer Erfahrung eine schwere intrauterine Mangelentwicklung vermeiden. Die hohe Zahl dystropher Neugeborener bei klinisch unauffälliger Schwangerschaft (30,1\% aller Fälle von intrauteriner Wachstumsstörung) führt ferner zu der Forderung einer allgemeinen endokrinologischen Vorsorgeüberwachung aller Schwangeren. Dies kann nur durch intensive Zusammenarbeit zwischen Praxis und Klinik realisiert werden.

Schlüsselwörter: Endokrinologisches Modell, Gesamtöstrogene, intrauterine Wachstumsverzögerung, nutritive Plazentafunktion, Pregnandiol.

\section{Résumé}

Un modèle d'endocrinologie pour le diagnostic du trouble de croissance intra-utérine, démontré par l'évaluation de l'estriolurie totale et de la prégnandiolurie dans 222 grossesses avec risque.

L'article présent traite d'un système endocrinologique praticable et sur pour le contrôle de la grossesse en cas de trouble chronique de la fonction placentaire nutritive. Les méthodes d'analyse hormonale employées ici sont simples et sures, et ne nécessitent $\mathrm{ni}$ isotope radioactif ni appareils de mesure spéciaux; elles peuvent donc être effectuées par n'importe quel laboratoire sans frais excessifs.

S'appuyant sur une statistique de 222 grossesses avec risque, on a réussi à prouver qu'en établissant simultanément un paramètre foetal (oestrogène) et un paramètre placentaire (prégnandiol), on peut diagnostiquer à temps et sans une grande marge d'erreur le risque du trouble de croissance intra-utérine. La seule analyse d'oestrogènes atteint un quotient d'exactitude de $90,1 \%$ pour $1,8 \%$ de résultats pathologiques faux et $8,1 \%$.de résultats normaux faux (Tab. I). En comparant, en outre, l'analyse du prégnandiol avec la précédente, on obtinet certes une augmentation des résultats hormonaux pathologiques faux jusqu'à $8,1 \%$, mais, par contre, une réduction à $2,7 \%$ du nombre plus important des résultats normaux faux. Ce groupe subsiduel ne comporte aucune nouveau-né dystrophique, mais 5 cas d'avortements spontanés menaçants (dont 3 complets) et un cas de transmission authentique. On voit donc que notre statistique, établie par la définition hormonale combinée, révèle le risque du trouble de croissance intra-utérine dans tous les cas, mais non celui d'un avortement spontané ou d'une transmission.

En cherchant à établir tôt (à partir de la 20ème scmaine) le diagnostic endocrinologique, on s'est aperçu que la prégnandiolurie faible, preuve d'un trouble de la fonction placentaire, se manifestait-des-semaines ou des mois avant une estriolurie peu élevée (Fig. 1). Ce résultat ne peut s'expliquer que par le fait que le degré d'estriolurie est, d'une façon générale, limité par le fonctionnement du foie et de l'écorce surrénale du foetus et non pas par le placenta. C'est ainsi que nos résultats confirment indirectement les études d'autres auteurs selon lesquelles, dans la synthèse des oestro-éléments, le foetus ne dépend pas du prégnénolon placentaire, mais peut constituer luimême la formule de base de novo à partir de 1'acétate. Cette voie de synthèse, indépendante du placenta, nous semble donc devoir jouer aussi un rôle quantitatif. Compte tenu du fait expérimental démontré que la capacité d'aromatisation du placenta ne semble pas être réduite même en cas de trouble grave de la fonction nutritive, 
notre étude prouve à son tour que l'estriolurie représente beaucoup plus un paramètre foetal que foetoplacentaire.

Sur le plan clinique, on peut en déduire surtout qu'en cas d'estriolurie pathologique, on se trouve déjà probablement en présence d'une lésion du foetus. De plus, on doit aussi établir un paramètre placentaire qui soit surtout sensible, c. à. d. de réaction rapide et précoce aux troubles du fonctionnement placentaire. Dans le travail présent, avec nos méthodes et au contraire d'autres résultats, la prégnandiolurie apparaît bien comme tenant ce tôle d'indicateur placentaire «sensible». La prégnandiolurie peu élevée étant suivie bien souvent d'une faible estriolurie avec enfant dystrophique, il semble prouvé également qu'elle est étroitement liée aussi à la fonction partielle nutritive du placenta.

Les réactions de synthèse consommatrices d'énergie dans le foetus ne peuvent pas naturellement avoir tout-à-fait lieu indépendamment du placenta. Si nous voulons donc expliquer nos observations fréquentes d'estriolurie normale même en cas de prégnandiolurie pathologique 'à long terme, nous devons admettre que le foetus opère une certaine compensation endocrinologique comme il en existe une, on le sait, dans le domaine respiratoire. On peut observer cette compensation placentaire sous la forme morphologique d'hyperplasie capillaire. Sa reproduction endocrinologique a lieu sous forme de courbes ondulatoires de prégnandiolurie (Fig. 1) où les phases de compensation (angiopoïèse) et de dépression (angiolyse etc.) rendent «visibles» les deux processus concurrents dans le placenta. L'unité de fonction foeto-placentaire se manifeste enfin sur le plan endocrinologique en ceci qu'à une phase de compensation placentaire respectivement plus longue chez le foetus répond une hausse compensatoire d'oestrogènes très nette (Fig. 1), tandis que la prégnandiolurie décroissante s'accompagne surtout de phases de stagnation dans l'estriolurie, signe d'une croissance foetale retardée. C'est ainsi que l'étude présente expose pour la première fois les rapports qui existent entre la morphologie placentaire et l'endocrinologie foetoplacentaire.

En résumé des facteurs ci-dessus mentionnés et à partir des quatre combinaisons possibles d'estriolurie et de prégnandiolurie, on peut élaborer un système de quatre groupes de risque (Tab. II) reposant sur les quatre thèses suivantes:
1. Estriolurie = paramètre foetal (non foeto-placentaire);

2. prégnandiolurie = paramétre de la fonction placentaire nutritive;

3. capacité de compensation endocrinologique du foetus;

4. capacité de compensation endocrinologique du placenta.

Ce modèle nous permet d'interpréter les résultats de notre statistique comme suit: $\mathrm{La}$ fréquence des nouveaux-nés dystrophiques augmente du groupe de risque I (estriolurie et prégnandiolurie normales, pas d'enfants dystrophiques) au groupe de risque II (seule prégnandiolurie pathologique, $11,5 \%$ d'enfants dystrophiques), puis au groupe de risque III (seule estriolurie pathologique, $26 \%$ d'enfants dystrophiques) jusqu'au groupe de risque IV (les deux paramètres hormonaux pathologiques, 55,4\% d'enfants dystrophiques). Grâce à ce modèle, il nous est donc possible d'évaluer le degré de risque du retardement de la croissance intra-utérine. C'est ainsi qu'un hormonurie du groupe de risque II est typique pour la gestose EPH légère ou commençante. Un bon traitement appliqué à temps maintient une hausse normale d'oestrogènes avec, souvent, des valeurs de prégnandiol encore basses. $\mathrm{Si}$, toutefois, la patientè reste sans contrôle ni thérapie, l'hormonurie du groupe II rejoint souvent la courbe du groupe IV, avec accroissement considérable du danger pour le foetus (Fig. 2).

On reconnaît enfin de plus en plus en médecine périnatale qu'une thérapie de la fonction placentaire nutritive soumise à un trouble chronique ne peut avoir des chances de succès qu'à condition d'être appliquée à long terme, ce qui présuppose un diagnostic précoce. Nos propres recherches prouvent qu'on peut déceler par l'évaluation combinée des oestrogènes et du prégnandiol une réduction de la fonction placentaire nutritive avant même que n'apparaisse une lésion du foetus, ce qui permet de prendre des mesures therapeutiques préventives à long terme qui, selon notre expérience, empêchent une malnutrition intra-utérine grave. Le nombre élevé des nouveaux-nés dystrophiques consécutifs à des grossesses cliniquement normales $(30,1 \%$ de tous les cas de trouble de croissance intra-utérine) nous amène également à recommander un controle endocrinologique préventif général de toutes les femmes enceintes, ce qui n'est possible qu'à condition de collaboration étroite entre les cabinets de consultation et l'hôpital.

Mots-clés: Fonction placentaire nutritive, modèle endocrinologique, oestrogènes totaux, prégnandiol, retardement de la croissance intra-utérine.

\section{Bibliography}

[1] Allen, W. M. in discussion of Hunt, A. B., W. M. McConafey: Pregnancy associated with diseases of the adrenal glands. Amer. J. Obstet. Gynec. 66 (1953) 970

[2] Appleby, J. J., J. K. Norymberski: The Urinary Excretion of 17-Hydroxycorticosteroids in Human Pregnancy. J. Endocr. 15 (1957) 310
[3] Berle, P.: Der Wert von Hormonbestimmungen für die Beurteilung der Plazentafunktion in der Spätschwangerschaft. Dtsch. med. Wschr. 98 (1973) 2146

[4] Christensen, A., D. Froyshov, P. Fylling: Hormone and Enzyme Assays in Pregnancy IV. The human chorionic somatomammotrophin, placental cystine-aminopeptidase, progesteron and the urinary 
estrogens in pregnancies complicated with essential hypertension, mild or severe pre-eclampsia. Acta endocr. (Kbh.) 77 (1974) 344

[5] Cleary, R. E., R. Depp, R. Pion, N. Chuchel: Relation of $C_{19}$ Stcroid sulfates in cord plasma to maternal urinary estriol. Amer. J. Obstet. Gynec. 106 (1970) 534

[6] Fliegner, J. R. H., Irene Schindler, J. B. Brown: Low Urinary estriol Excretion During Pregnancy Associated with Placental Sulfatase Deficiency or Congenital Adrenal Hypoplasia. J. Obstet. Gynaec. Brit. Cwlth 79 (1972) 810

[7] FRANCE, J. T.: Levels of $16 x$-Hydroxydehydroepiandrosterone, Dehydroepiandrosterone and Pregnenolone in Cord Plasma of Human Normal and Anencephalic Fetuses. Steroids 17 (1971) 697

[8] France, J. T., R. J. Seddon, G. C. Liggins: A Study of a Pregnancy with Low Estrogen Production Due to Placental Sulfatase Deficiency. J. clin. Endocr. Metab. 36 (1973) 1

[9] Frandsen, V. A., G. Stakemann: The Site of Production of Oestrogenic Hormones in Human Pregnancy. Acta endocr. (Kbh.) 38 (1961) 383

[10] Hellig, H., D. Gattereau, Y. Lefevre, E. Bolté: Steroid Production from Plasma Cholesterol. I. Conversion of Plasma Cholesterol to Placental Progesterone in Humans. J. Clin. Endocr. Metab. 30 (1970) 624

[11] Keller, P. J., P. Bader, J. Schmid, U. Baertschi, C. Gerber, R. Soltermann, E. Kopper: Biochemical detection of fetoplacental distress in risk pregnancies. Lancet 2 (1971) 729

[12] Kuss, E.: Klinisch-chemische Untersuchungen zur Überwachung der gefährdeten Schwangerschaft. Gynäkologe 7 (1974) 124

[13] Lurie, A. O., D. E. Reid, C. A. Villee: The role of the fetus and placenta in maintenance of plasma progesterone. Amer. J. Obstet. Gynec. 96 (1966) 670

[14] Naeye, R. L.: Malnutrition. Probable Cause of Fetal Growth Retardation. Arch. Pathol. 79 (1965) 284

[15] Reynolds, J. W., B. L. MrRkIN: Urinary Steroid Levels in Newborn Infants with Intra-uterine Growth Retardation. J. clin. Endocr. Metab. 36 (1973) 576
[16] Robinson, H. P., W. R. Chatfield, R. W. Logan, F. Hall: Intrauterine Fetal Growth Retardation. A Comparison of Human Placental Lactogen, Urinary Oestriol and Biparietal Diameter Measurements. Ann. clin. Biochem. 11 (1974) 15

[17] Robinson, H. P., W. R. Chatrield, R. W. Logan, A. K. Tweedie, W. P. Barnard: A Scoring System for the Assessment of Multiple Methods of Monitoring Fetal Growth. J. Obstet. Gynaec. Brit. Cwlth 80 (1973) 230

[18] Siebert, W., C. Meitrnger, W. Vogt, P. Sandel: Serum-HPL bei intrauteriner Wachstumsretardierung während der Spätschwangerschaft. Geburtsh. u. Frauenheilk. 34 (1974) 520

[19] Spellacy, W. N., W. C. Buhr, S. A. BirK, K. K. Holsinger: Human placental lactogen levels and intrapartum fetal distress. Meconium-stained amniotic fluid, fetal heart rate patterns, and Apgar scores. Amer. J. Obstet. Gynec. 114 (1972) 803

[20] Spona, J., H. Janisch: Diagnose der Plazentainsuffizienz durch radioimmunologische Untersuchungen des Serum-HCG und Serum-HPL. Wien. klin. Wschr. 84 (1972) 285

[21] Sybulskr, S.: In vitro estrogen biosynthesis from testosterone by homogenates of placentas from normal pregnancies and pregnancies complicated by intrauterine fetal malnutrition and diabetes. Amer. J. Obstet. Gynec. 105 (1969) 1055

[22] Taylor, T., J. R. T. Coutts, M. C. Macnaughton: Estrogen Formation in Human Foetuses Perfused with $\left[4-{ }^{14} \mathrm{C}\right]$ Progesterone. Acta endocr. (Kbh.) 75 (1974) 595

[23] Telegdy, G., J. W. Weeks, D. F. Archer, N. Wrevist, E. Diczfalusy: Acetate and Cholesterol Metabolism in the Human Foeto-Placental Unit at Midgestation. Acta cndocr. (Kbh.) 63 (1970) 119

[24] Wolfrum, R.: Zur Bestimmung des Pregnandiols im Urin bei Schwangeren. Ärztl. Lab. 20 (1974) 335

[25] Wolfrum, R.: Zur Bestimmung der Gesamtöstrogene im Urin bei Schwangeren. Ärztl. Lab. 19 (1973) 329

[26] Wolfrum, R., J. Holweg, R. Gidion: Sind Penicilline während der Schwangerschaft für den Feten harmlos? Clin. Chim. Acta 57 (1974) 125

Dr. rer. nat. Reinhold Wolfrum Allgemeines Krankenhaus Heidberg Chemische Abteilung Tangstedter Landstraße 400 D-2000 Hamburg 62/Germany 